\title{
NEGOTIATING APPROPRIATION - Later Safavid Adaptations of Chinese Blue-and-white Porcelain
}

he beginnings of Chinese blue-and-white porcelain in Safavid Persia
are naturally connected with trade between China and Persia, which
took place during the Yongle reign (1402-1424), when Sino-Persian exchange entered a new era. It is worth remembering here that between 1406-1433 China launched seven major maritime expeditions that reached as far as the Indian Ocean, Ceylon, eastern coast of Africa, Persian Gulf, and Persia. Interestingly, all of these brave voyages were conducted by a Muslim admiral named Zheng He (1371-1433). ${ }^{1)}$ It is due to these courageous actions that the Chinese gained sophisticated geographical knowledge and established important trade connections. It is worth noticing here that the vast crew taking part in these trips also included merchants. In 1433 the expeditions were stopped all of a sudden most probably because of the fact that China's economy was not yet sufficiently developed to continue foreign trade expansion, ${ }^{2)}$ which was a rather marginal activity for the overall economic situation of the country. ${ }^{3)}$ As later history proved, this thoughtlessly

1) Dreyer (2007).

2) Lunna (2005: 13-17).

3) Some scholars see here the rather obvious rivalry between eunuchs and court as the most important reason for stopping maritime expansion. After Zheng He's death, bureaucracy intervened and the documents with information on preparing the next expedition were lost (Fitzgerald 1974: 452). 
and rather short-sightedly made decision turned out to be unfavourable for China, when trade was successfully conducted by the Europeans.

Between the 1460s and the end of the century, trade prospered uninterruptedly ${ }^{4)}$ and the key spot on Persia's map was the port island Hormuz, through which many different kinds of cargo landed and allowed goods to be transported between the Middle East and Europe. Afanasi Nikitin, a Russian merchant, noticed with astonishment, and perhaps some degree of disappointment, "a vast emporium of all the world; you find there people and goods of every description, and whatever thing is produced on earth you find it in Hormuz. But the duties are high, one tenth of everything." ${ }^{5} \mathrm{He}$ also was not very fond of the Chinese goods, especially porcelain, which he considered "cheap."

The year 1515 brought radical change in the situation, when Hormuz was controlled by the Portuguese and declared independence. ${ }^{7)}$ Heavy tolls began to be executed on shipping goods to different ports in the Arabian Sea and the Indian Ocean. Unfortunately, the degree of influence it had on that how much porcelain reached Iran during that time is unknown, but one thing is certain - large shipments arrived at the coasts of both Spain and Portugal. ${ }^{8)}$ As described below, the Persian response to Chinese blue-and-white porcelain during those times was marginal, so it is hard not to agree with Golombek stating that "the quantity of porcelain being imported was not sufficiently large or affordable to pose a threat to the local industry."')

1622 was another important date, as this was when the Portuguese were finally driven away from Hormuz by the Persian coalition with the English. Trade was relocated to Gombroon, renamed Bandar 'Abbās, which was a safer port. ${ }^{10)}$ It is worth mentioning here that during the preceding years, which led to this event, there was fierce competition between the Portuguese, the English, and the Dutch for share in the silk trade, which was probably the most lucrative activity. 1600 and 1602 brought the establishment of the East India Company in both of these countries and the consequent opening of
4) Golombek (2013: 24).
5) Ferrier (1986: 422-423).
6) Ferrier (1986: 422-423).
7) $\operatorname{Kauz}(2010: 43)$.
8) Golombek (2013: 24).
9) Golombek (2013: 25).
10) Floor (2006: 250). 
factories along the sea routes made steady transport of goods between Europe and China a new possibility. ${ }^{11)}$

It is worth mentioning the fact that the first blue-and-white porcelain reached Europe in 1602 after one of the Portuguese carracks' cargo was captured by the Dutch. Additionally, attacks on Spanish and Portuguese ships were very lucrative, which led to the Dutch government allowing such operations by sanctioning the capture of enemy ships and permitting the division of spoils between the crew members. As can be easily deduced, this soon became a significant strategy and a good source of merchandises such as porcelain from China. ${ }^{12)}$ Chinese porcelain with its whiteness and delicacy won over the Dutch and at the beginning goods were shipped from China via Batavia but since the Dutch settlement of Taiwan in 1624, the cargo could be sent directly from China through Chinese agents in Taiwan. As stated by the VOC (Vereenigde Oostindische Compagnie; The Dutch East India Company, officially known as the United East India Company) records gathered by Volker, the amount of porcelain reaching Europe was staggering. More than 3 million vessels were shipped by the VOC between 1604 and 1657. What is even more astonishing, one ship, in 1636, was able to carry as much as 136,164 pieces. ${ }^{13)}$ It is worth noticing that shipping cargo to Europe was not the only activity undertaken by the VOC. Golombek ${ }^{14)}$ states:

Orders were also taken from the many Dutch agencies in ports around the Indian Ocean and Arabian Sea for shipment inland. The entry point for Persia was Bandar Abbas (Gombroon). One record from 1623 reports: "Fine and coarse porcelain may be sold here in substantial quantities." ${ }^{15)}$ In 1629 some 4,000 pieces of porcelain were loaded into ships bound for Gombroon. Some 4,000-5,000 coffee cups were sent in 1634. Also in 1634, 10 large dishes were sent for the Safavid ruler Safi I, and in 1635 nearly 100,000 coffee cups arrived in Gombroon. An enormous quantity of porcelain arrived in 1638 - more than 33,000 pieces. Caravans travelling from India, Central Asia, and Arabia also brought goods, including "China-ware," to Iran, according to Thomas Herbert, who travelled to Iran in the years 1627-1629.

\footnotetext{
11) Chaudhuri (2006: 6).

12) Parthesius (2010: 36).

13) Volker (1954: 39, 41-42).

14) Golombek (2013: 24).

15) Dunlop (1930: 23).
} 
Interestingly, as Golombek ${ }^{16)}$ suggests, not all of the these wares ended up sold on the open market and there are sources stating that some of the goods were used as bribes or presents to the Safavid officials. The gifts' recipients included not only the viziers, but also the shah. An interesting example here can be the French ambassador, who eight years after establishment of the trading company gave such gifts as: jewels, spices, paintings and 519 porcelain vessels to the shah in $1671 .^{17)}$

Important changes in trade dynamics took place after the fall of the Ming dynasty in 1644 . The VOC had to look for other sources of supplies, as some difficulties in obtaining goods from China arose. In response, other nations for example Persia and Japan - switched sides in a sense and began exporting instead of importing ceramics. Between 1672 and 1682 porcelains from Japan were sent in large quantities to Persia. In the years from 1654 to 1682 Persian pottery wares were included in the VOC records. ${ }^{18)}$ Understandably, the amount of exported Persian ceramics could not compete with the impressive quantities of the Chinese or Japanese shipments and was "approximately 1,600 pieces annually exported to Batavia over a period of 25 years, making a grand total of about 40,000 pieces [...]." ${ }^{19)}$

It should be strongly stressed here that even though the fall of Ming dynasty did not stop smaller pottery centres from producing porcelain, however, the "Revolt of the Three Feudatories" directed against the Kangxi Emperor had a serious consequence, resulting in the loss of Jingdezhen manufacture to the destruction of fire. Pottery production ceased from 1674 to 1676 and in 1680 officials were at last directed to resume the imperial kilns. 1683 brought end of the civil war and henceforth foreign trade was resumed.

Golombek's collaborative study presents the correlation of China's presence and absence with the Persian response of making derivative forms. She marked the periods of Chinese porcelain existence in Persia or lack thereof into the following:

1. 1622-1652 when Chinese porcelain was exported to Persia continuously;

2. 1654-1682 when Persia took an active part as an exporter of ceramics due to decline of porcelain production in China;

\footnotetext{
16) Golombek (2013: 24).

17) Golombek (2013: 26). See also: Du Mans (1890: 335-337).

18) Golombek (2013: 26). See also: Volker (1954: 113-116).

19) Volker (1954: 116).
} 
3. 1683-1722 when Jingdezhen resumed pottery making and export throughout the world. ${ }^{20)}$

Even though this correlation is valuable to the research conducted by the author, it does not always prove right when the decorative motifs are compared to each other individually, as will be shown in the following examples.

An important issue to notice is that when foreign artistic stimuli reach another culture the initial phase is marked by curiosity, vast interest, and a need to replicate. Therefore, the early Safavid period seems to be dominated by more literal adaptations ${ }^{21)}$ of the Chinese repertoire while in later years decorative motifs had to thrive in order to survive the competition of not only native, but also European influences.

The appearance of foreign stimuli evoked a plethora of responses from local artists, ${ }^{22}$ one of them being the treatment of the foreign element as foreign and hence not making any significant changes, which meant being more literal while using it. Figure 1 (a) is a good example of such an approach. The detail shows a literal adaptation of the artemisia leaf motif, presented in figure 1 (b) and it is clearly noticeable that the Persian artist took care of portraying the leaf with attention to details, such as veins, petiole, and complementing ribbons with loops and their endings. An interesting feature follows the framing line around the motif. The positioning of the leaf may seem odd, as it is a mirror image of the source, but it is worth remembering that Chinese artists liked to rotate auspicious symbols and put them in different positioning. Persians observed this behaviour and applied it to their adaptations as well.

A second response was to try to satisfy everybody and this involved editing the decorative motifs by adding, deleting, or substituting its vital elements. Very often the editorial processes were concurrent and resulted in interesting mixed adaptations. An interesting example of bringing two

20) Golombek (2013: 26).

21) The reason, for which the author prefers to use the term "adaptation" in her research, was thoroughly explained in one of her recent publications (Macioszek 2017: 87-104, 266-267).

22) A more in-depth analysis of 120 dishes performed by the author can be read in her PhD dissertation entitled Safavid Adaptations of Chinese Kraak Porcelain Dishes. She distinguishes four basic kinds of adaptations: literal, edited (abridged, substituted, extended, and mixed), altered, and free. An article in Polish briefly explaining the issue of types of adaptations is also available. See: Macioszek (2015: 77-100). 
distinctive motifs into one, and hence of edited extended adaptation, is shown in Figure 1 (c). The single peach motif surrounded by leaves, an example of which can be seen in figure $1(\mathrm{~d})$, was extended by adding a four petalled flower, similar to the one in figure 1 (e), at the base of the fruit. The end result is a mesmerizing ensemble that could satisfy the desire for novelty as well as those looking for a traditional peach.

The third response is about allowing more freedom in adapting foreign motifs, which are treated as if they were their own. An ideal example of such an approach can be seen in the detail shown in figure 1 (f) portraying a double fruit motif, in this case open pomegranates. One can easily notice that the motif is Chinese in origin and similar to the possible sources shown in figures $1(\mathrm{~g})$ and $1(\mathrm{~h})$ as the basic characteristics such as clouds, sun, placement of the fruits and leaves were preserved. However, the scenery was altered and looks in a more fantastic way with a spiral added to the sun surrounded by a series of dots and lines, as well as something at the bottom that could be interpreted as a pond with two pseudo fish inside. ${ }^{23)}$

There are also cases when only the general idea was adapted and the native forms coexist alongside Chinese elements like in case of the example shown in figure 1 (i) portraying the central composition of a Safavid plate. The detail presents a seated man assisted by a servant. This idea probably derives from similar Chinese depictions of a lady or a man with an assistant or servant bringing or holding writing utensils or, as in the example in figure 1 (j), a vase with flowers. The Persian adaptors made the characters easily recognizable as native with such elements as long-necked bottle held by the man, but at the same time, the clothing he wears is Chinese with the typical loose sleeves and so are the elements of nature surrounding him such as clouds, tree, and bamboo leaves.

Products in the seventeenth century had to struggle for attention as new stimuli from European art were encroaching and gaining in popularity. ${ }^{24)}$ This also had an impact on the negotiation processes between the Chinese and

23) According to the most recent findings of the author, the pseudo fish most probably are reminiscences of motifs used in thirteenth-fourteenth century tiles, such as the one stored in the Metropolitan Museum of Art in New York (accession number: 41.165.12): http://www.metmuseum.org/art/collection/search/450428 (accessed: 15.02.2017).

24) The most noticeable examples are uses of single point perspective or translucent clothing and vessels. All of these aspects can be observed in the miniature painting Fitna Astonishing Bahrām Gūr by Muhammad Zamān (1675, Iṣfahān, Iran; inventory no.: MS Or. 2265, f. 213r, British Library). 
Persian decorations and resulted in interesting abstract forms among the Safavid adaptations of Chinese blue-and-white porcelain. Among those which the author finds most interesting are fantastic landscapes and balustrades, strange roots as well as Chinese elements presented in altered forms but used among the native.

The Chinese way of depicting landscapes on blue-and-white porcelain stems from Chinese traditional painting. Interestingly, Chinese painters did not use single point perspective to give a feeling of distance; instead they depicted the objects closer to them by placing them at the bottom of the painting and proceeding upwards, without reducing the size of the further objects, which were placed at the top of the painting. A good example here could be the detail of Chinese dish shown in figure 2 (c), which has two distinctive layers and the size of objects located in both of them are of almost identical size.

Depictions of landscapes gained popularity in Persia probably due to the fact that they gave the viewers an opportunity to discover a piece of an unknown land together with its architecture, boats, rivers, and other aspects of every-day life. Persians enjoyed painting fantasy scenes on their adaptations with pagoda-like buildings, vegetation, mountains, rivers and ships. They are usually placed in the centre of the dishes for greater exposition. Persian potters often followed the Chinese idea and made three distinctive layers, like in the example shown in figure 2 (b), although they also liked to depict landscapes and scenes in two layers divided by a river, as in the dish presented in figure 2 (a).

Sometimes elements known from kraak porcelain were used as parts of fantasy scenes. ${ }^{25)}$ The flower basket motif, shown in detail in figure 2 (f), which was an attribute of one of the Eight Immortals in China, was portrayed with excessively long root stand, as it can be seen in figure 2 (d), and as a three-part pagoda-like structure - in figure 2 (e).

Even though some imaginary landscapes have the three distinctive layers, they are barely visible due to the density of the complementing vegetation and abstract elements added to the image, as it can be observed in the example shown in figure $2(\mathrm{~g})$. In other examples, the viewer must look at the dishes from different angles to actually see the entire story depicted in the surface of the dish like in the Persian dish presented in figure 2 (h).

25) More on the characteristics of kraak porcelain can be read in Rinaldi (1989). 
There are also interesting cases when the landscape is so abstract that the perspective is actually absent and this way the view can be enjoyed from each side of the dish (fig. 2 (i)). Other times only one layer is present and a fragmentary decoration of scrolls and flowers is shown, like in the dish shown in figure $2(\mathrm{j})$.

Balustrades proved to be another motif fruitful for abstraction. In the case of their Chinese depictions, they usually complement the flower basket, like in the detail of a kraak dish shown in figure 2 (l), set among vegetation or as part of a scene with or without figures. In case of Persian abstract adaptations, the balustrades were often depicted in abundance like in the two examples, which can be seen in figures $2(\mathrm{j})$ and $2(\mathrm{k})$ : on the left with birds sitting on them complemented by an altered lotus flower and on the right a highly imaginative and abstract depiction of balustrades with vegetation and a butterfly in the centre of the dish.

Among the abstract forms from the sixteenth or seventeenth century there are vessels depicting strange root-like structures dividing their surface into parts as in the case of the vase shown in figure $2(\mathrm{~m})$. The author thinks that these roots in fact could have derived from Jiajing (1521-1567) bowls ${ }^{26}$ that depict the so-called Orchid Pavilion Gathering, which was a literary convocation in celebration of the annual Spring Purification Festival. It took place in China on the third day of the third moon. People would gather near the water and play games, as it can be seen in the detail of Chinese painting in figure 2 (o). Therefore, the bent line in the Persian adaptation could be a river. Strange roots or rivers were also used on the lips characteristic for kraak porcelain dishes, as in the dish shown in figure 2 (n).

Chinese blue-and-white porcelain motifs in their abstract forms were also placed among the typically native decorations such as luster or scrolls used on metalwork. The vase from the Museum of Islamic Art in Berlin, which can be seen in figure 3 (a), is an interesting example of a fantastical foreign landscape and scrolls, which were also used in other products such as metalwork shown in detail in figure 3 (b). Chinese porcelain motifs like cranes and fire symbols were also set among native scrolls painted in colourful slips, as it can be observed in the vase shown in figure 3 (c).

Safavid revival of luster decorations was also used to cover vessels with elements inspired by kraak porcelain such as the flower basket in the centre

26) An example can be seen at Robert McPherson Antiques, stock number 24492: http://orientalceramics.com/index.php/product/bowl-7/ (accessed: 16.02.2017). 
(fig. 3 (d) and fig. 2 (f)). Other times the central compositions of the vessels were decorated with native elements painted in colourful slips and borders with Chinese kraak porcelain petal panels and dividers (fig. 3 (e)).

Not only landscapes or vegetation were interesting for the Persians, but also the Chinese character shò (寿; 壽) meaning "longevity" known from the Chinese sources (fig. 3 (g)) was sometimes used as decoration in an altered and simplified form, for example on bottlenecks (fig. 3 (f)).

In order to portray the negotiation processes better, the author would now like to analyse a few chosen examples of entire vessels and their decorations. It should be noted here that Persian artists were experts in creating an illusion of similarity and "smuggling" in abstraction at the same time. A good example of such a process can be observed in figure 4 (a) portraying a Safavid vessel which was an adaptation of a Chinese kraak porcelain dish type VII. Every other petal panel originates from the palm leaf motif with complementing tassels and ribbons similar to the Chinese detail in Figure 4 (b). The Persian artist, however, decided to cut the ribbons, duplicated some of them and attached the tassels at two ends of the leaf. Altogether, the end result is a mesmerizing abstract form of the motif. Other petal panels depict something difficult to trace as it has clouds, two stems and a construction of what is, in all probability, a pomegranate on bamboo sticks. The author's estimation is that it originates from fruits complemented by vertically organised smaller ones among other vegetation and an insect similar to the detail in figure 4 (c). The vertical structure of the fruits was multiplied in the Safavid adaptation and used instead of the insect. There is also another trace of inspiration possible, namely from the outer walls of the kraak bowls, such as the detail in figure 4 (d), which could explain the coexistence of bamboo sticks supporting the pomegranate, two fruits at its side and bulgy ground below the structure. The bracket frame encircling the central composition most probably originates from a similar one with scrolls used among the Chinese kraak porcelain dishes (fig. 4 (e)). The dividers are a mixture of two kinds of Chinese kraak dividers - one with string of jewels (fig. 4 (f)) and the other with the upper part decorated with a swastika key fret (fig. 4 (g)). The central composition is an interesting blend of two Chinese compositions; namely, the tree was inspired by the deer motif (fig. $4(\mathrm{~h})$ ) while the duck with vegetation came from the duck at the pond motif (fig. 4 (i)).

Last but not least is an interesting pan from the Museum of Islamic Art in Berlin presented in figure 5 (a). The bottom of the inside is decorated with a mixture of elements known from Chinese sources, such as the egret in side 
view with complementing vegetation (figure $5(\mathrm{c})$ ). The lotus flower, in a form similar to the ones used, for example, in Safavid miniature paintings (figure 5 (b)) and in Chinese depictions of water scenes with birds (figure 5 (c)), was multiplied, as were the clouds known from other Chinese porcelains (figure 5 (d)). The inner walls consist of water plant compositions known from kraak porcelain similar to the one shown in detail (c) and an interesting addition was made to the decoration, namely a piece of phoenix tail, similar to the depiction portrayed in detail (e), set among the vegetation.

The outer walls are even more interesting and complex (fig. 6 (a)). The scene consists of such Chinese elements as: a tree, a dark dot, and a series of lines indicating water (fig. 6 (b)). Three birds in flight were placed under stylized, scrolled, and shaded clouds (fig. 6 (c)). Two figures on the left also bear traces of Chinese inspiration in clothing - one person is dressed in a darker-hued loose gown and the other in a lighter one. Additionally, one of the figures faces left, just like his Chinese counterpart (fig. 6 (d)). Even details such as the vegetation, ground and the rock's multilayered structure as well as the leaves are present (fig. 6 (d)). One may also spot European elements, which were also portrayed in tiles (fig. 6 (e)), such as the hats of the second man and his clothing as well as the woman playing a string instrument. The main character sits on a chair and the peculiar formation attached to the chair's base is an adaptation of scrolls with the "sapienti nihil novum (nothing is new to the wise)" inscription, which appeared in a rare group of Chinese export bowls and dishes with heraldic-style shields. ${ }^{27)}$

As it can be observed in the above analysed examples, since Chinese products entered Persia they began to be treated as prospective sources of inspiration for further developments. Persian artists treated Chinese motifs as mysterious seeds with potential to grow and expand into unusual forms. Even though Chinese decorations sometimes underwent drastic changes throughout the acts of appropriation and adaptation, one aspect remained common for all of them - they flourished and grew into new amazing selves. Persian soil during the Safavid period proved to be a good place for the evolution of Chinese decorations and the constant winds of negotiation between remaining faithful to the native spirit or following the sublime foreign stimuli had never been so fruitful.

27) Bowl, The British Museum, London, 1957,1216.19, 17.3 x $34.6 \mathrm{~cm}$, http://www. britishmuseum.org/research/collection_online/collection_object_details/collection_ image_gallery.aspx?assetId=35369001\&objectId=255538\&partId=1. 


\section{BIBLIOGRAPHY:}

Chaudhuri $2006=$ Kirti N. Chaudhuri, The Trading World of Asia and the English East India Company: 1660-1760, Cambridge University Press, 2006.

Dunlop 1930 = Hendrik Dunlop, Bronnen tot de geschiedenis der Oostindische compagnie in Perzië (Sources to the History of the East India Company in Persia), The Hague, M. Nijhoff, 1930.

Du Mans 1890 = Raphaël Du Mans, Estat de la Perse en 1660 (State of Persia in 1660), Paris, E. Leroux, 1890.

Dreyer 2007 = Edward L. Dreyer, Zheng He: China and the Oceans in the Early Ming Dynasty, 1405-1433, Pearson Longman, 2007.

Ferrier 1986 = Ronald Ferrier, "Trade from the Mid-fourteenth Century to the End of the Safavid Period”, in: The Cambridge History of Iran, vol. 6, 1986.

Fitzgerald 1974 = Charles P. Fitzgerald, Chiny. Zarys historii kultury (China. A Short Cultural History), Państwowy Instytut Wydawniczy, Warszawa, 1974.

Floor 2006 = Willem M. Floor, The Persian Gulf: A Political and Economic History of Five Port Cities, 1500-1730, Mage Publishers, 2006.

Golombek 2013 = Lisa Golombek, Robert B. Mason, Eileen Reilly, Patty Proctor, Persian Pottery in the First Global Age: The Sixteenth and Seventeenth Centuries, Brill, 2013.

Kauz 2010 = Ralph Kauz, Aspects of the Maritime Silk Road: From the Persian Gulf to the East China Sea, Otto Harrowitz Verlag, 2010.

Lunna 2005 = Zhong Lunna 钟伦纳, “郑和下西洋中止的最重要原》” (Major Causes for the Termination of Zheng He's Voyages). 郑和研究 (Zheng He yan jiu), 4, 2005:13-17.

Macioszek 2015 = Amelia Macioszek, „Safawidzkie adaptacje chińskich talerzy typu kraak”, Studia Azjatystyczne 1/94 (2015): 77-100, DOI: http://dx.doi.org/10.14746/ sa.2015.1.06.

Macioszek 2017 = Amelia Macioszek, "Copy, Imitation, Transformation, Translation or Adaptation? Terminological Entanglements Around Describing Derivative Works”, in: Newest Art History: Wohin geht die jungste Kunstgeschichte. Tagungsband zur 18. Tagung des Verbandes österreichischer Kunsthistorikerinnen und Kunsthistoriker, 2017: 87-104, 266-267.

Parthesius 2010 = Robert Parthesius, Dutch Ships in Tropical Waters. The Development of the Dutch East India Company (VOC) Shipping Network in Asia 1595-1660, Amsterdam University Press, 2010.

Rinaldi 1989 = Maura Rinaldi, Kraak Porcelain - A Moment in the History of Trade, Bamboo Publishing, 1989.

Volker 1954 = T. Volker, Porcelain and the Dutch East India Company: As Recorded in the Dagh-Registers of Batavia Castle, Those of Hirado and Deshima and Other Contemporary Papers; 1602-1682, E.J. Brill, 1954. 


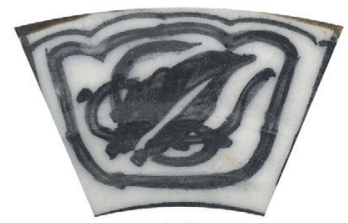

(a)

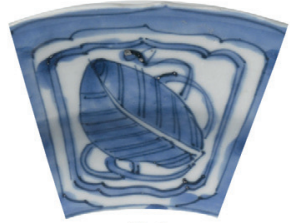

(b)

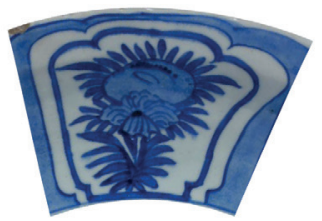

(c)

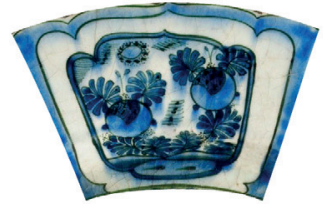

(f)

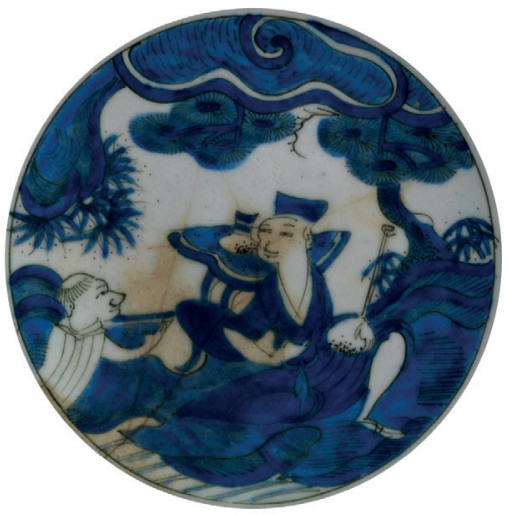

(i)

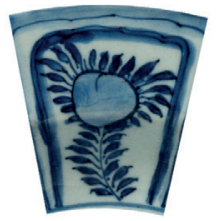

(d)

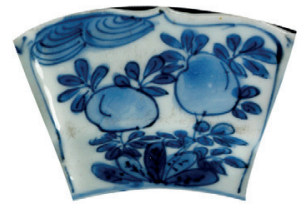

(g)

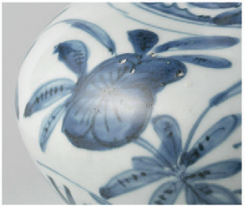

(e)

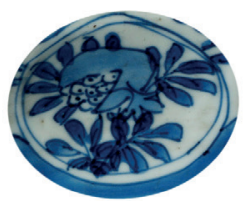

(h)

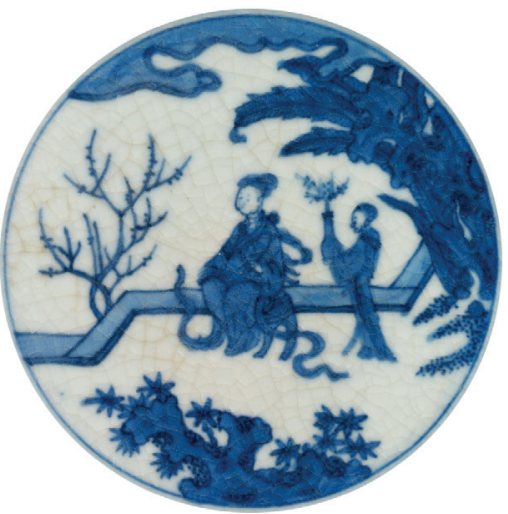

(j)

Figure 1. Four responses to the Chinese stimuli:

(a) Plate 'detail', fritware with underglaze cobalt blue, H. 3.5 cm, Kirman, Iran, circa 1600-1700. Amsterdam, Rijksmuseum, BK-NM-12419. (c) Public Domain; (b) Dish 'detail', porcelain with underglaze cobalt blue, 5.4 x 28.4 cm, Jingdezhen, China, before 1613. Amsterdam, Rijksmuseum, NG-1977-167-W. (๑) Public Domain; (c) Dish 'detail', fritware with underglaze cobalt blue, 8.7 x $44 \mathrm{~cm}$, Iran, sixteenth century. London, Victoria and Albert Museum, 444-1878. ( ) Victoria and Albert Museum, London; (d) Dish 'detail', porcelain with underglaze cobalt blue, D. $27.9 \mathrm{~cm}$, Jingdezhen, China, circa 1600. London, Victoria and Albert Museum, FE.23-1970. (C) Victoria and Albert Museum, London; (e) Kendi 'detail', porcelain with underglaze cobalt blue, 16 x 14.5 cm, Jingdezhen, China, before 1613. Amsterdam, Rijksmuseum, NG-1977-175-W. ( ) Public Domain; (f) Dish 'detail', fritware with underglaze cobalt blue and black, 4.9 × $26.8 \mathrm{~cm}$, Iran, seventeenth century. London, Victoria and Albert Museum, 2795-1876. ( $\odot$ Victoria and Albert Museum, London; (g) Dish 'detail', porcelain with underglaze cobalt blue, D. 21 cm, Jingdezhen, China, 1573-1620. London, Victoria and Albert Museum, C.579-1910. ㄷ Victoria and Albert Museum, London; (h) Dish 'detail', porcelain with underglaze cobalt blue, D. $20.6 \mathrm{~cm}$, Jingdezhen, China, 1573-1620. London, Victoria and Albert Museum, C.574-1910. ( $)$ Victoria and Albert Museum, London; (i) Plate 'detail', fritware with underglaze cobalt blue and black, D. $28.6 \mathrm{~cm}$, Iran, sixteenth century. London, Victoria and Albert Museum, 2796-1876. (c) Victoria and Albert Museum, London; (j) Dish 'detail', porcelain with underglaze cobalt blue, D. $14.6 \mathrm{~cm}$, Jingdezhen, China, 1522-1566. London, Victoria and Albert Museum, C.579-1910. ๑ Victoria and Albert Museum, London. 


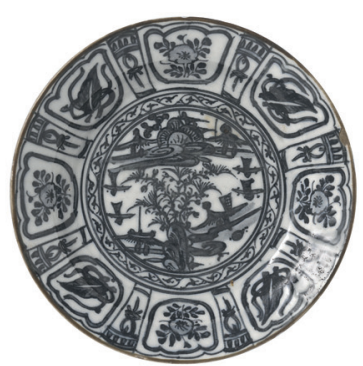

(a)

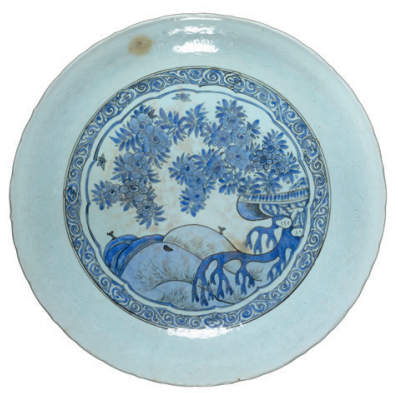

(d)

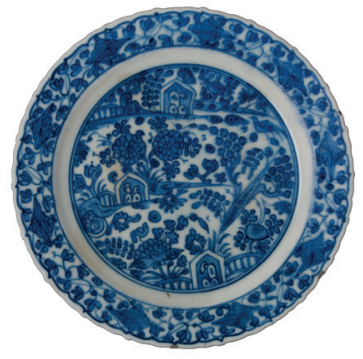

(g)

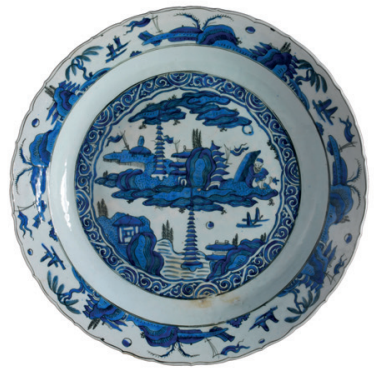

(b)

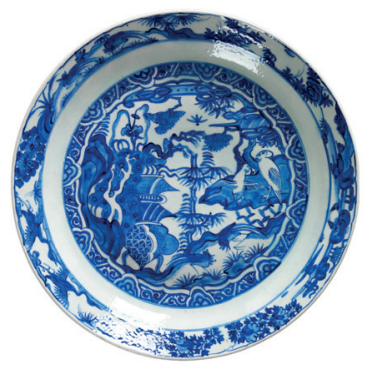

(e)

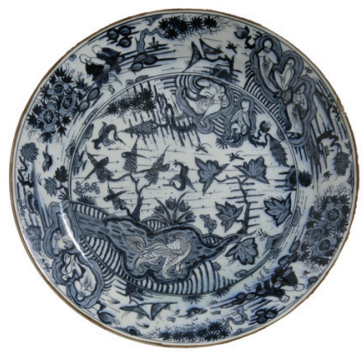

(h)

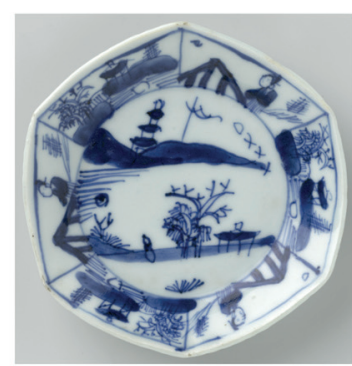

(c)

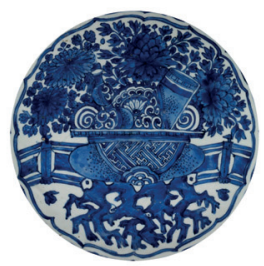

(f)

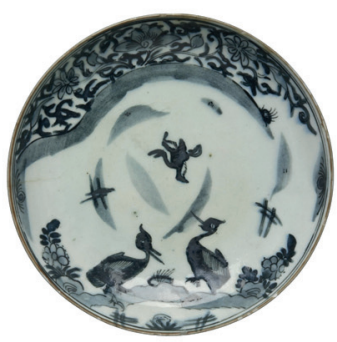

(i) 


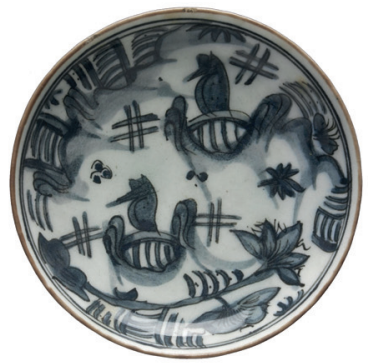

(j)

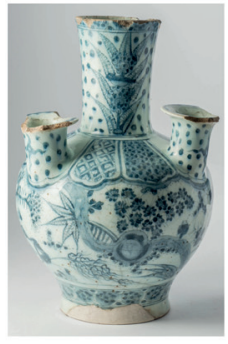

(m)

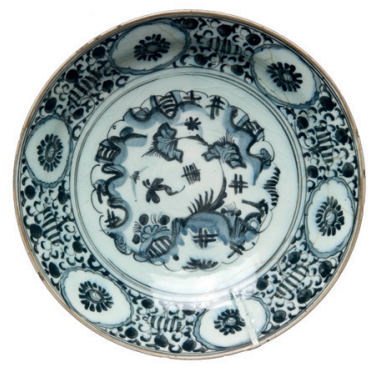

(k)

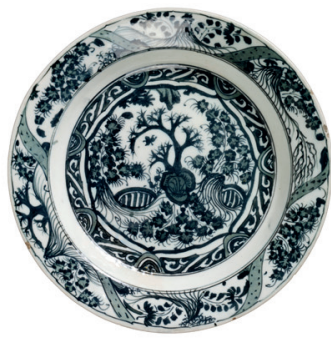

(n)

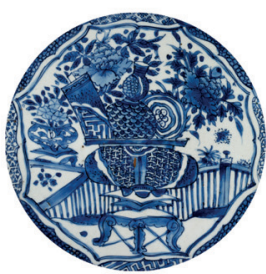

(l)

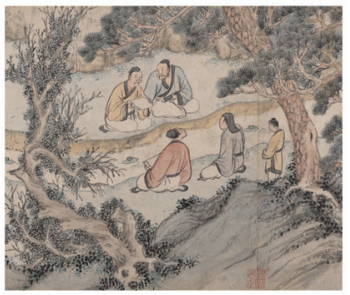

(o)

Figure 2 continued:

(j) Dish, fritware with underglaze cobalt blue, $3.3 \times 14.2 \mathrm{~cm}$, Iran, 1650-1700. London, Victoria and Albert Museum, $2691 \mathrm{~A}-1876$. (C) Victoria and Albert Museum, London; (k) Dish, fritware with underglaze cobalt blue, 8 x 32.8 cm, Iran, 1650-1700. London, Victoria and Albert Museum, 1139-1876. (c) Victoria and Albert Museum, London; (l) Dish 'detail', porcelain with underglaze cobalt blue, D. 50 cm, Jingdezhen, China, 1615-1630. London, Victoria and Albert Museum, CIRC.568-1921. (C) Victoria and Albert Museum, London; (m) Vase, fritware with underglaze cobalt blue, 22.3 x $14.8 \mathrm{~cm}$, Iran, sixteenth century. Berlin, Museum of Islamic Art, 1872,768. (C) Museum für Islamische Kunst, Staatlichen Museen zu Berlin, photographer: Johannes Kramer; (n) Dish, fritware with underglaze cobalt blue, 4.7 x $24.3 \mathrm{~cm}$, Iran, seventeenth century. London, Victoria and Albert Museum, 2705-1876. (c) Victoria and Albert Museum, London; (o) Qian Gu, Gathering at the Orchid Pavilion 'detail', hand-scroll, ink and colour on paper, image: 24.1 x $435.6 \mathrm{~cm}$, overall with mounting: 24.8 x $1248.1 \mathrm{~cm}$, China, datable to 1560 . New York, The Metropolitan Museum of Art, 1980.80. (c) Public Domain.

Figure 3. Chinese blue-and-white motifs among white :

(a) Vase, fritware with cobalt blue and luster decoration, 31 x $18.3 \mathrm{~cm}$, Iran, seventeenth century. Berlin, Museum of Islamic Art, I. 4215. (c) Museum für Islamische Kunst, Staatliche Museen zu Berlin, photographer: Johannes Kramer; (b) Candle holder, brass, cast, engraved and inlaid with black compound, 34 x $19.7 \mathrm{~cm}$, Iran, around 1600. Berlin, Museum of Islamic Art, S 1199. (C) Museum für Islamische Kunst, Staatliche Museen zu Berlin, photographer: Christian Krug; (c) Bottle, stone paste polychrome painted under transparent glaze, 33.7 x 15.9 cm, Kirman, Iran, 1650s. New York, The Metropolitan Museum of Art, 14.64.2. (c) Public Domain; (d) Dish, fritware with underglaze cobalt blue and over-glaze luster, 5.4 x $23 \mathrm{~cm}$, Iran, seventeenth century. Berlin, Museum of Islamic Art, I. 4192. () Museum für Islamische Kunst, Staatliche Museen zu Berlin, photographer: Johannes Kramer; (e) Dish, stone paste with underglaze cobalt blue and colourful strips, 6.4 x $30.5 \mathrm{~cm}$, Kirman, Iran, seventeenth - early eighteenth century. New York, The Metropolitan Museum of Art, 20.120.165. ( ) Public Domain; (f) Bottle, fritware with underglaze cobalt blue and black, 28.5 x $16.1 \mathrm{~cm}$, Iran, circa 1650-1700. London, Victoria and Albert Museum, $1127-1876$. (c) Victoria and Albert Museum, London; (g) Bowl, porcelain with underglaze cobalt blue, D. 22 cm, Jingdezhen, China, $1464-1487$. Kuala Ramplin, Malaysia, Nanhai Marine Archaeology Sdn. Bhd., W-4995. ( ) Sten Sjostrand. 


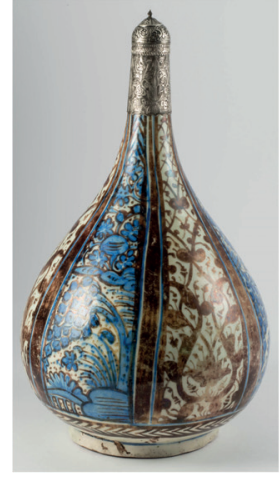

(a)

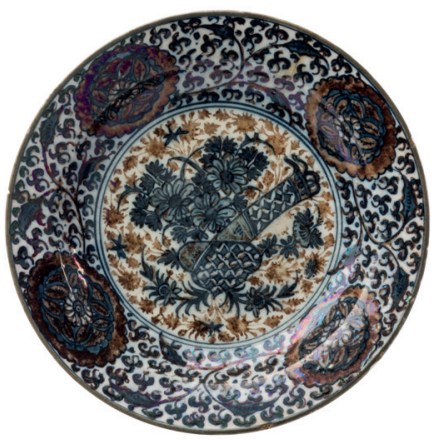

(d)

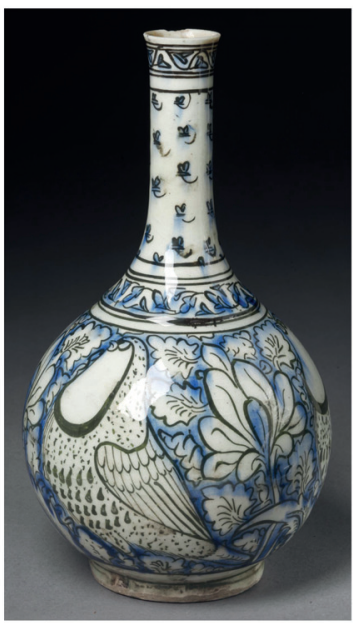

(f)

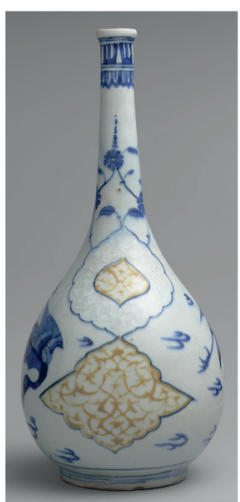

(c)

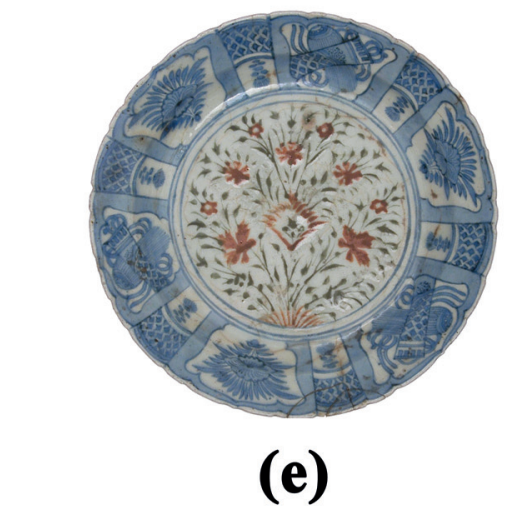

(e)

(b)

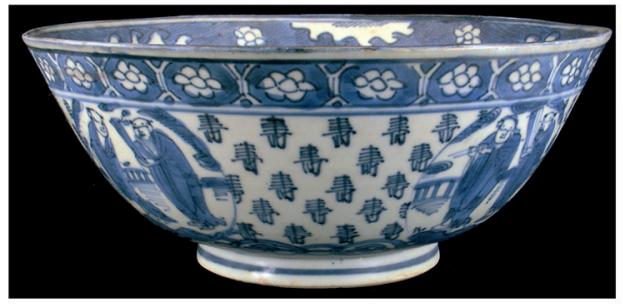

(g) 


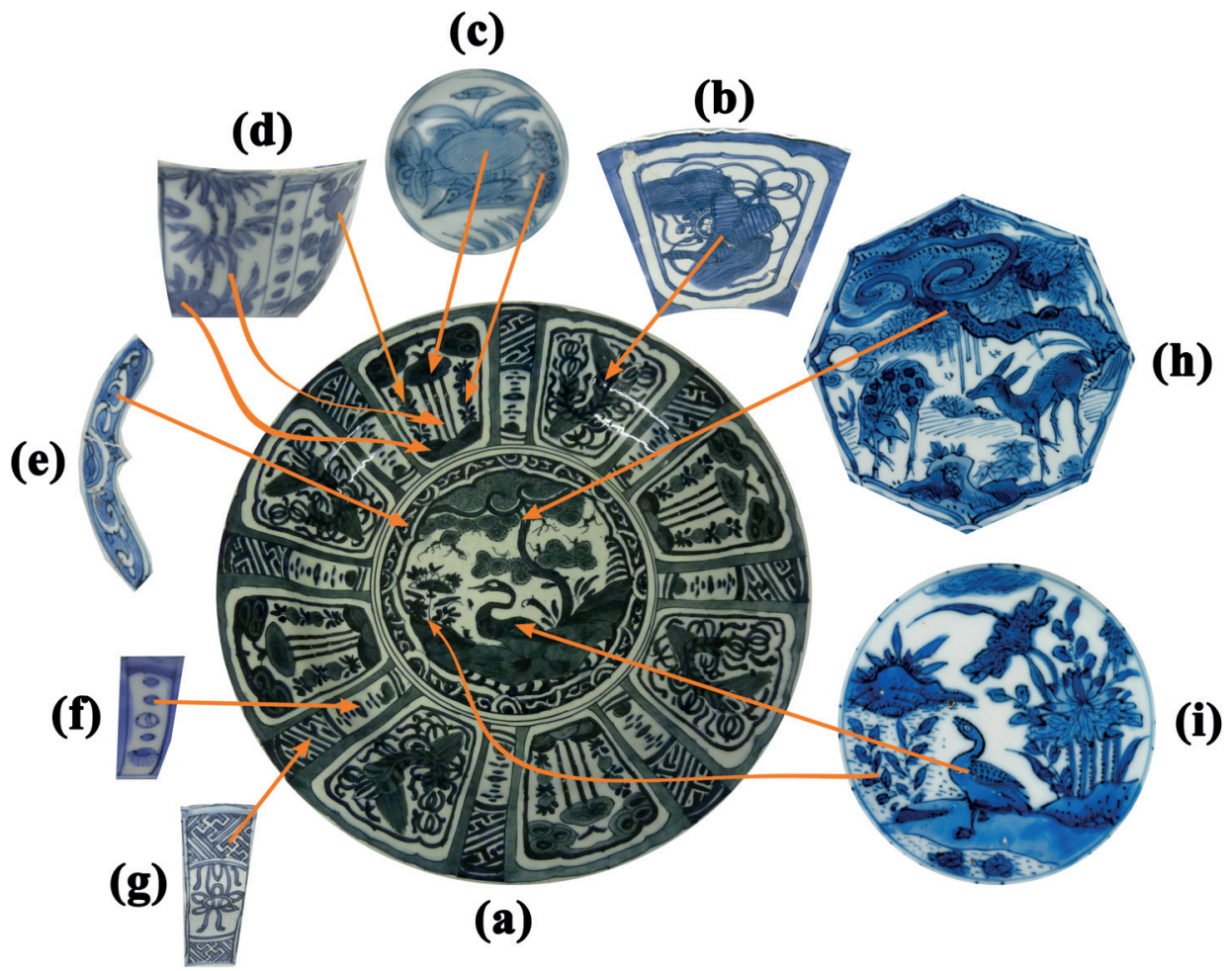

Figure 4. Hidden abstract forms among close adaptations:

(a) Dish, fritware with underglaze cobalt blue and black, 7.4 x $42.5 \mathrm{~cm}$, Iran, seventeenth century. London, Victoria and Albert Museum, 2819-1876. () Victoria and Albert Museum, London; (b) Dish 'detail', porcelain with underglaze cobalt blue, $10 \mathrm{x} 50.7$ cm, Jingdezhen, China, before 1613. Amsterdam, Rijksmuseum, NG-1977-127-W. (c) Public Domain.

(c) Bowl 'detail', porcelain with underglaze cobalt blue, 3.5 x $11.2 \mathrm{~cm}$, Jingdezhen, China, before 1613. Amsterdam, Rijksmuseum, NG-1978-127-10502-W. ( $)$ Public Domain; (d) Bowl 'detail', porcelain with underglaze cobalt blue, 6.8 x $10.3 \mathrm{~cm}$, Jingdezhen, China, before 1613. Amsterdam, Rijksmuseum, NG-1978-127-9503-W. ( P Public Domain; (e) Dish 'detail', porcelain with underglaze cobalt blue, 3.2 × $21.2 \mathrm{~cm}$, Jingdezhen, China, before 1613. Amsterdam, Rijksmuseum, NG-1978-127-4026-W. () Public Domain; (f) Saucer-dish 'detail', porcelain with underglaze cobalt blue, 3.7 x 20.6 cm, Jingdezhen, China, circa $1600-1624$. Amsterdam, Rijksmuseum, AK-KOG-1751. ( ) Public Domain; (g) Dish 'detail', porcelain with underglaze cobalt blue, 9.7 x 50.5 cm, Jingdezhen, China, circa 1600-1625. Amsterdam, Rijksmuseum, AK-NM-13086. @ Public Domain; (h) Dish 'detail', porcelain with underglaze cobalt blue, 4 × $21 \mathrm{~cm}$, Jingdezhen, China, 1580-1630. London, Victoria and Albert Museum, 396-1903. (c) Victoria and Albert Museum, London; (i) Dish 'detail', porcelain with underglaze cobalt blue, D. 13.7 cm, Jingdezhen, China, 1573-1620. London, Victoria and Albert Museum, C.163-1923. ( ) Victoria and Albert Museum, London. 
(e)

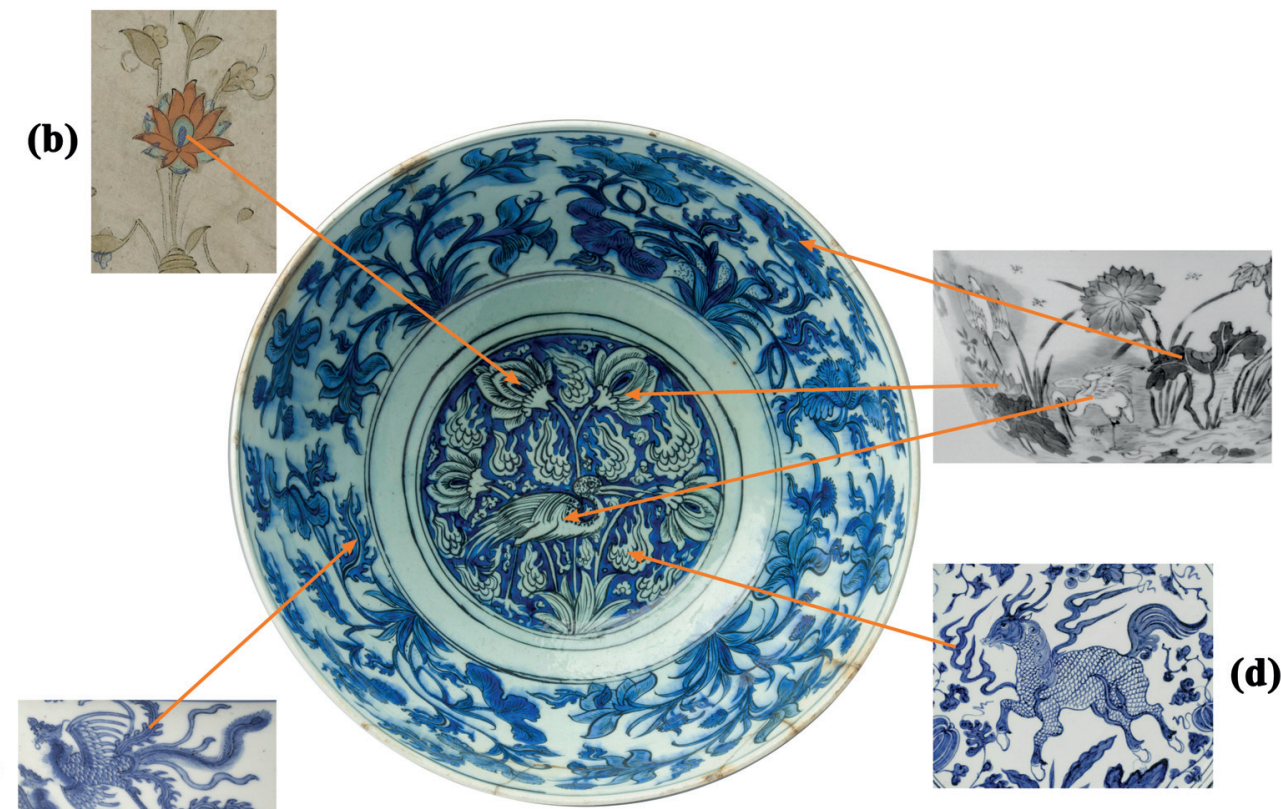

(a)

Figure 5. Mixture of elements known from different Chinese and native sources:

(a) Pan, fritware with underglaze cobalt blue and black, $24 \mathrm{~cm}$ x $45.7 \mathrm{~cm}$, Iran, first quarter of the seventeenth century. Berlin, Museum of Islamic Art, I. 4225. ๑ Museum für Islamische Kunst, Staatliche Museen zu Berlin, photographer: Johannes Kramer; (b) Man in a Red Robe Playing a Musical Instrument 'detail', anonymous, ink, opaque watercolour and gold on paper, 16.4 x 9.5 cm, Iran, 1570-1590. Amsterdam, Rijksmuseum, RP-T-1993-462-(R). (c) Public Domain; (c) Bowl 'detail', porcelain with underglaze cobalt blue, H. 19.5 cm, Jingdezhen, China, 1675-1725. Baltimore, The Walters Art Museum, 49.248. ( ) CC0 license. (d) Charger 'detail', porcelain with underglaze cobalt blue, $7.2 \times 45.7 \mathrm{~cm}$, Jingdezhen, China, circa 1350. Amsterdam, Rijksmuseum, AK-RBK-1965-88. ( ) Public Domain; (e) Bowl 'detail', porcelain with underglaze cobalt blue, $9.8 \times 21.7 \mathrm{~cm}$, Jingdezhen, China, circa 1680-1720. Amsterdam, Rijksmuseum, AK-RBK-16272. ๑ Public Domain. 


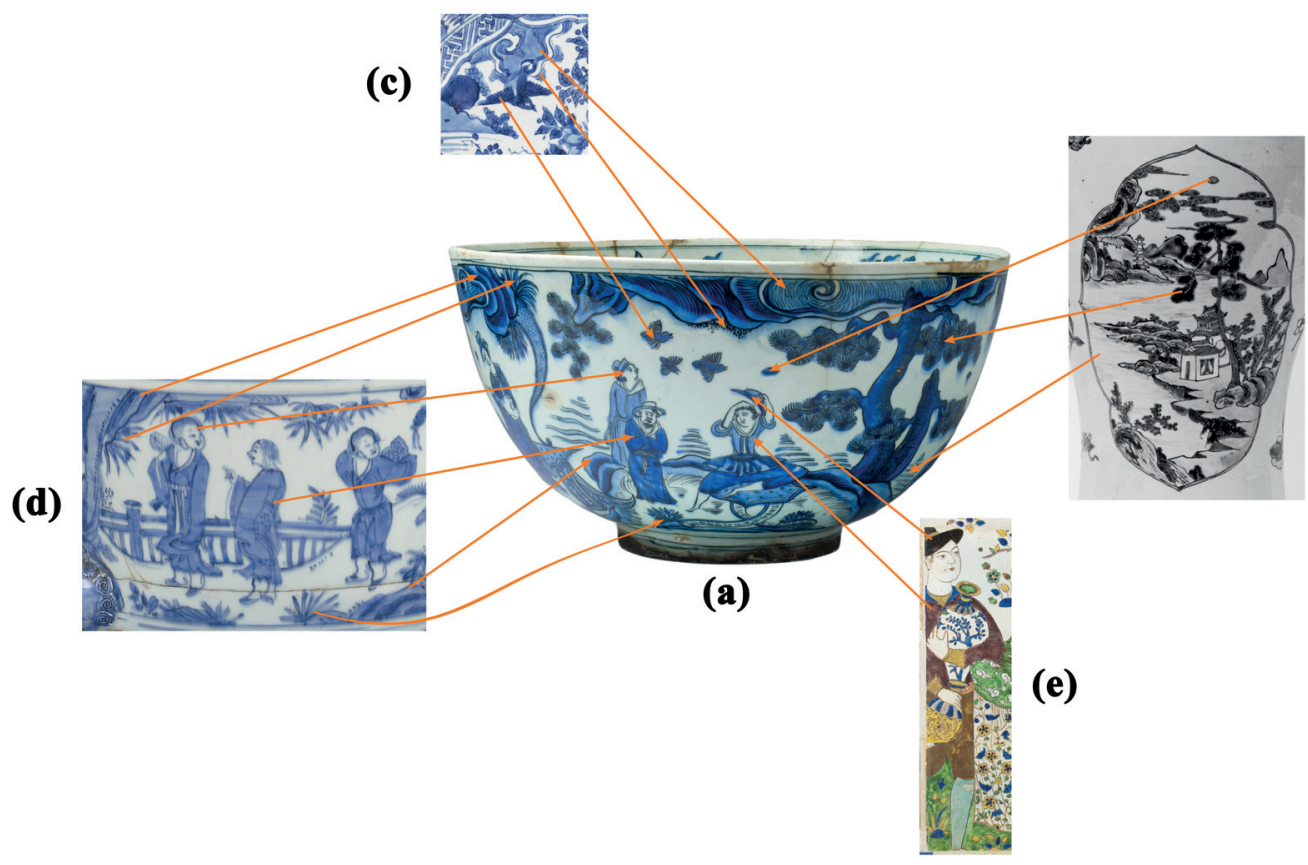

(b)

Figure 6. European elements among Chinese landscape:

(a) Pan, fritware with underglaze cobalt blue and black, 24 x $45.7 \mathrm{~cm}$, Iran, first quarter of the seventeenth century. Berlin, Museum of Islamic Art, I. 4225. ( ) Museum für Islamische Kunst, Staatliche Museen zu Berlin, photographer: Johannes Kramer (b) Mantle garniture 'detail', porcelain with overglaze enamels, $\mathrm{H} .43 .9 \mathrm{~cm}$, Jingdezhen, China, mid eighteenth century. Baltimore, The Walters Art Museum, 49.2113. (C CC0 license; (c) Dish 'detail', porcelain with underglaze cobalt blue, D. $50.5 \mathrm{~cm}$, Jingdezhen, China, circa 1600-1624. Amsterdam, Rijksmuseum, AK-RBK-16385. ( ) Public Domain; (d) Temple incense burner 'detail', porcelain with underglaze cobalt blue, 24.4 x $30.7 \mathrm{~cm}$, Jingdezhen, China, 1604. Baltimore, The Walters Art Museum, 49.2207. (c) CC0 license; (d) Tile panel 'detail', stone paste polychrome glazed within black wax resist outlines, panel: 115.6 x $138.7 \mathrm{~cm}$, probably Isfahan, attributed to Iran, first quarter seventeenth century. New York, The Metropolitan Museum of Art, 03.9a. (c) Public Domain. 